International Research Journal of Management, IT \& Social Sciences
Available online at https://sloap.org/journals/index.php/irjmis/
Vol. 6 No. 5, September 2019, pages: 242 260
ISSN: 2395-7492
https://doi.org/10.21744/irjmis.v6n5.737

\title{
Development of District Health System Model Policy Implementation for Improving Health Services
}

\author{
Dominikus Minggu ${ }^{\text {a }}$ \\ Fred. L. Benu ${ }^{\text {b }}$ \\ Frans Gana ${ }^{c}$ \\ Petrus Kase $^{d}$
}

Article history:

Received: 09 March 2019

Accepted: 31 July 2019

Published: 06 September 2019

\section{Keywords:}

district health system;

dominic;

health service;

policy implementation;

responsiveness;

\begin{abstract}
National Health In implementing the autonomy function of decentralization, The Government of TTU District has rearranged the form and method of administering the district health or health development system which is organized in the District Regulation No. 09/2015. The objective of the study is to analyze how the development of a District Health System (DHS) model influences health services in the District of TTU, NTT. The research is Mix method approach. The results of quantitative: District Health System (DHS) directly influences Responsiveness (RPS), then Responsiveness (RPS) influences Policy Implementation and Policy Implementation (PI) influencing Health Services (HS); with Goodness of Fit: Chi-Square 125,625; probability 0.073; degree of freedom 104 Cmin / Df 1,208; GFI 0.946; CFI 0.993; RMSEA 0.032 and AGFI 0.802. At $\alpha=0.01$. Results of qualitative that Implementation of TTU district health system policy has been implemented through the provision of health services and the preparation of the TTU District Middle Plan. It was concluded that the new model: Implementation of Dominic BGK's District Health Sisitem Policy can be implemented comprehensively to improve health services and achieve the highest degree of public health. The mode is recommended to be implemented in other autonomous districts.
\end{abstract}

2395-7492@ Copyright 2019. The Author. This is an open-access article under the CC BY-SA license (https://creativecommons.org/licenses/by-sa/4.0/) All rights reserved.

\section{Author correspondence:}

Dominikus Minggu,

State Nusa Cendana University, Kupang, Indonesia.

Email address: domimere31@gmail.com

\footnotetext{
a State Nusa Cendana University, Kupang, Indonesia

${ }^{\text {b }}$ State Nusa Cendana University, Kupang, Indonesia

${ }^{c}$ State Nusa Cendana University, Kupang, Indonesia

${ }^{\mathrm{d}}$ State Nusa Cendana University, Kupang, Indonesia
} 


\section{Introduction}

Public health is a combination of theory (science) and practice (art) that aims to prevent disease, prolong life and improve the health of the population (society). "For the first time, public health has commitment, resources, and powerful interventions. What is missing is this. The power of these interventions is not matched by the power of health systems to deliver them to those in greatest need, on an adequate scale, in time. This lack of capacity arises ... in part, from the fact that research on health systems has been so badly neglected and underfunded." (WHO, 2007)

Solving problems with incomplete health systems, inadequate facilities, lack of education, weak understanding of surveillance, including vaccines, etc, should have been resolved simultaneously. Health system has to focus on people (people-centered) not just on the service provider. Health system should pay attention to existing failures because we do not have basic infrastructures. Research needs to examine the infrastructures based on the right data (evidence base) to solve health problems in order to achieve the objectives of national development (Agarwal et al., 2017; Aldim et al., 2018).

The ultimate goal (outcome) of National Development of Indonesia is achieving the physical and spiritual wellbeing of all people. This human development benchmark is measured by the Human Development Index (HDI). In the global context, Indonesia's HDI for 2018 is 71.39. Based on the United Nations Development Program (UNDP) Development Program standard, the index places Indonesia in the category of high-level human development and ranks together with Vietnam at 116 of 189 countries and regions. However, there are still significant differences between one region and other regions.

The Indonesian Central Bureau of Statistics (2018) recorded that the Human Development Index of East Nusa Tenggara Province was ranked 32nd out of 34 provinces. TTU District ranks 12th out of 22 districts/cities in NTT Province with HDI (62.65) below the provincial (NTT) HDI (64.39) and lower than the National HDI (71.39) (BPS, 2019).

As the situation of the HDI encourages the Indonesian Government's vision of sovereign, independence and having personality based on mutual cooperation, the ministry of health has determined health development goals: (1) increasing public health status; (2) Increased responsiveness; and (3) Community protection against social and financial risks in the health sector

Meanwhile, in 2014, Law No. 23 of 2014 was passed on. It is about District Government (on the functional division or assignment, Minimum Service Standards (SPM) and Good Governance of District Government), which replaced the Law No. 32 of 2004 on decentralization. Elucidation to Law Number 32 of 2004 contains health issues or matters which have been handed over to District governments that consist of 4 sub-matter as follows: (1) Health efforts (2) Human resources (HR) Health (3) Pharmaceutical preparations, medical devices, food and beverages (4) Community empowerment

Some responsibility of central government are absolutely decentralized - it becomes absolutely the affairs of District government, and there are responsibilities that are optionally concurrent, particularly in some main sectors and obligatory affairs related to basic services. The Health Sector is one of the six autonomous basic service sectors.

The strategy of the central and District governments to achieve national health targets is the central government sets national targets in the health sector to be achieved in the upcoming RPJMN. The RPJMD of NTT for 2018-2023 is set with its vision: "NTT rises to actualize a prosperous society in the Unitary State of the Republic of Indonesia". "NTT rises will be measured by (1) the quality of human resources, the level of prosperity, business opportunities and reducing the level of poverty of the people of NTT. (2) Being able to achieve equal life and equal prosperity level to other regions relying on their own abilities and strengths. NTT Sejahtera is measured through (1) fulfilling the basic needs of the community both clothing, food, and shelter. (2) There is no any form of restrictions/discrimination, both between individuals, genders, and regions with a social justice-based development approach. There are 5 (five) missions, the first mission is related to the health sector - to create a just and prosperous society - with health development priorities is focused on stunting prevention/handling. In the health sector, national targets refer to the National Health System in accordance with Presidential Regulation No. 72 of 2012 Article 2 paragraph 1: Health is a healthy condition, both physically, mentally, spiritually and socially which enables everyone to live productively, socially and economically. and in the District level refers to District Health System.

The effort to accelerate health development in TTU District, the form and method of implementing health development or the TTU District Health System (DHS of TTU) has been rearranged in the Local Regulation of the District Health System Number 09 2015. This system can also actualize community protection as recipients and providers of health services (patient safety, safety provider and community safety).

Minggu, D., Benu, F. L., Gana, F., \& Kase, P. (2019). Development of district health system model policy implementation for improving health services. International Research Journal of Management, IT and Social 
The District Health System is intended to make DHS as the foundation for developing health development policies in TTU District, and can be utilized as guidelines, forms and ways of District health management either by local governments, the private sector, or the community, as well as related parties by referring to the national health system through system approach.

Based on this notion, a study entitled "Development of a Model of District Health System Policy Implementation for Improving Health Services in North Central Timor District, East Nusa Tenggara Province in 2019. The objective of the research is to analyze the development of the District Health System (DHS) model implementation approach which influences health services using a systems approach in TTU District, NTT Province.

\section{Materials and Methods}

\section{Research Types and Design}

This research was conducted using Mix Method approaches - quantitative and qualitative. The type of quantitative research (phase I) was observational analytic cross-sectional design, survey. Phase II was descriptive qualitative phenomenological research. The stages of the research were as follows:

In this phase I, identification of health service issues in the community related to responsiveness and DHS policy implementation in the district based on each indicator and it was adapted by researcher according to 1) WHO (2009) The System Framework "The Building Blocks of Health System: Aims and Attributes; The Dynamic Architecture and Interconnectedness of the Health System Building Block: 2) National Health System (SKN), 3) "Social-Ecological Model of Health Behavior", Health Belief Model 4) "Social Determinant of Health Rainbow" and 5) DHS of the TTU District. The theoretical concept was used to create a Conceptual Model for Developing DHS Policy Implementation Models for Improving health services in the TTU District, NTT Province.

\section{Phase II}

The Research conducted at this stage was qualitative which was done in-depth interviews and focus group discussions. The District Health System Policy (DHS) Implementation Model in the District of TTU

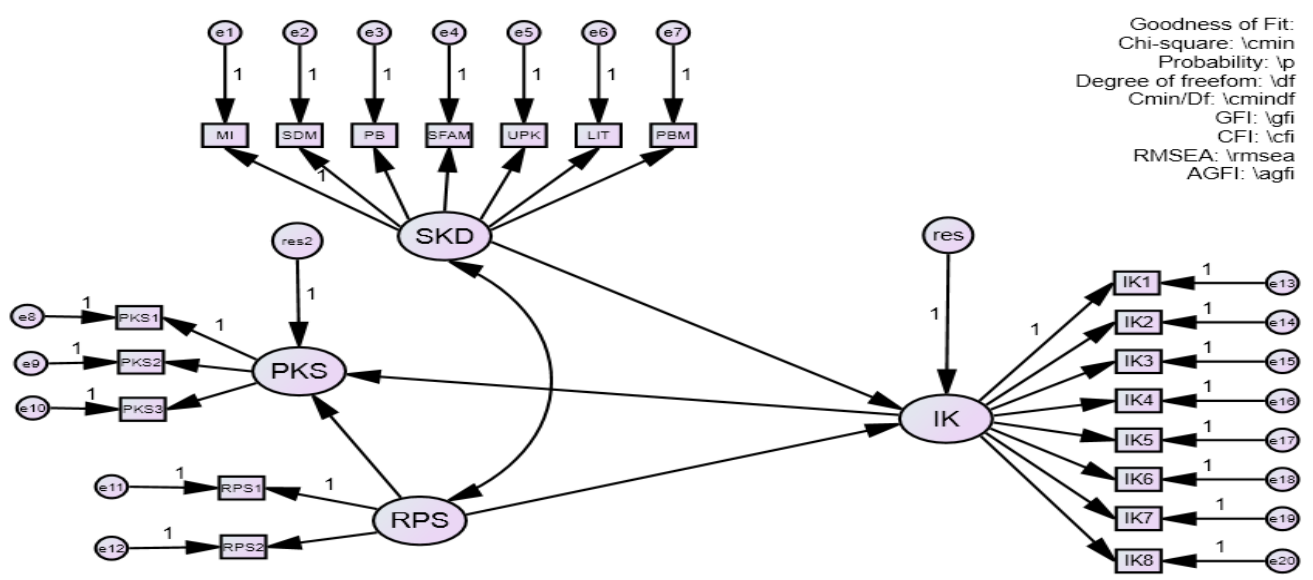

Figure 1. The conceptual model with Latent Variable and Indicator

The conceptual model in Figure 1 was formed by 4 latent variables, namely: (1) District Health System (DHS), Responsiveness (RPS), Health Services (HS) and Policy Implementation (PI). Erdogan latent variables (Dependent) were health services and policy implementation while exogenous latent variables (Independent) were the District District Health System (DHS) and responsiveness. The four variables were formed by $20 \mathrm{observed} / \mathrm{manifest}$ variables or indicators. Health Services variable with 3 (three indicators), Implementation variable with 8 indicators; District Health System Variable (DHS) 7 indicators and Responsiveness variable with 2 indicators.

Observed/manifest variables or indicators that made up endogenous/dependent latent variables: (1) Health Services: Access Coverage, Quality of Safety, Occurrence of Health Improvement (level and equity) Improved Health (level and Equity), and (2) Policy Implementation: Policy Standards and Targets, Resources, Inter-Organizational 
Relations, Implementing Agency Characteristics, Socio-Economic and Politics, Disposition and Bureaucratic Structure.

Observed/manifest variables or indicators that made up the exogenous/Independent latent variables: (1) District Health System (DHS): Information management and health regulation, Human resources (HR), Financing, Pharmaceutical Preparation and Medical Devices, Health Efforts, research and the development of Health, and Community Empowerment (2) Responsiveness: Responsiveness and improvement in efficiency and fairness (Improved efficiency and fairly).

Population, Sample Size and Sampling Technique of Population

The population in this study consisted of two parts, namely: First was for the quantitative research and second was for the qualitative research. The first population was health workers in hospitals and health centers; The second population was leaders and policymakers as well as Community Leaders (TOMA), Religious Leaders (TOGA), Health Cadres, Shamans and PKK Activists. The total population of 19 people from TEAM 19 was acting as Formulators of the DHS District Regulation and the heads of SKPD and District Parliament were 39 people

Sample

The first research sample units were: Health Officers in the TTU District Health Office, and health officers of District Hospitals in TTU District, NTT Province. The second research sample unit consisted of Leaders and Policy Makers and Community Leaders (TOMA), Religious Leaders (TOGA) Health Cadres, Shamans and PKK Mothers.

Sample Size

The determination of sample size in the research was based on the same scope of study (Kuntoro, 2009). Sample size calculations for health workers using the Lemeshow formula for a finite population with a sample size of 208 people. The second stage of research. Samples taken in the Community consisted of Religion Figure and Crosssectoral Team 19 and District Offices leaders across sectors. The sample size for FGD consisted of 19 people, and for Interview: 10 people.

\section{Sampling technique}

The first stage of research sampling was done in two-stage random sampling technique. In this study, researchers took the area of health centers and hospitals with a geographical approach and then involving the individual elements in the selected sub-districts. TTU District has 24 sub-districts / 26 Puskesmas. A sampling of Health Officers in hospitals and health centers was done by simple random sampling.

\section{Research Instruments}

The instrument used in the first phase of the research was a questionnaire and interview guidelines. To maintain the validity and reliability of the questionnaire, the researchers had consulted with 5 experts in the health and social fields to see the validity of the contents of the questionnaire. Then, the researchers revised the questionnaire results of respondent filling in accordance with input from experts.

\section{Research Location and Time}

The research location was in the TTU District, East Nusa Tenggara Province.

a) The Puskesmas in the District of TTU was divided into 4 regions:

1) Eastern Region: Sub-districts of North Biboki, Biboki Moenleu, and South Biboki. Lurasik Health Center and OElolok Health Center

2) West Region: West Miomafo, Mutis, and East Miomafo District. Eban Health Center and Bajaepasu Health Center

3) Northern Region: Insana Utara, Insana, and Kefamenanu Town Districts Puskesmas Wini and Puskesmas Manamas

4) Southern Region: South Bikoomi District, North BPIomi and Central BPIomi. Puskesmas Noemuti and Puskesmas Oemeo

b) Kefamenanu General Hospital

Research time was determined to the completion of reporting which was approximately 6 months, consisting of: the first three months was to collect data. Another three (3) months was for analysis and writing of results.

Minggu, D., Benu, F. L., Gana, F., \& Kase, P. (2019). Development of district health system model policy implementation for improving health services. International Research Journal of Management, IT and Social Sciences, 6(5), 242-260. https://doi.org/10.21744/irjmis.v6n5.737 


\section{Research implementation}

The implementation of the first phase of the research included the development of the TTU District Health System Implementation Model to improve health services in the TTU District.

Modeling Steps:

1) Development of a model based on concepts and theories

2) Constructing the path diagram

3) Conversion of path diagrams into structural models

4) Selecting the input matrix

5) Assessing the problem of identification

6) Evaluate goodness of fit

7) Testing parameters: testing each parameter in SEM was done by t-test. The testing was carried out for:

8) Overall model testing: The test was made to see if the model, both structure and the measurement results were said to be good (fit) or not. It was said to be fit if the hypothetical and theoretical development of models was hypothetically supported by empirical data. There are several tests that could be used including Chi-Squared, Root Mean Square Residual (RMR), Root Mean Square Error of Approximation (RMSEA), Adjusted goodness of fit index (AGFI). If the non-significant chi-square, small RMR, RMSEA $<0.08$ or AGFI $>0.9$ indicate a good model (fit).

9) Testing the structural model can be observed through the coefficient of determination - R2 such as a regression analysis of R2 with values ranging from 0 to 1 , the model is said to be good when the coefficient gets bigger (close to 1).

10) Model Interpretation and Modification: If the model is good, it can be interpreted, but if it is not good, it needs to be modified. And thus there was a development of a new model of DHS Policy Implementation for improving health services in the TTU District, NTT Province.

The second stage of the research was carried out through FGD activities and in-depth interviews with informants using interview guidelines with structured and open-ended questions. Researcher as key instruments. Retrieval of data was done until the data seemed to be representative and saturated. The researcher stopped collecting data and then made the transcript of the research report and recommendations.

\section{Data Processing and Analysis Methods}

\section{Quantitative Analysis}

Data were analyzed and interpreted by testing hypotheses - using a computer program SPSS for Windows Release 19 and AMOS 20.0 with following stages: (1) Univariate Analysis (2) Structural Equation Modeling (SEM) analysis to analyze all variables studied using Confidence Interval (CI) ) of $95 \%(\alpha=0.005)$.

\section{Qualitative Analysis}

The method used to analyze the data in this study was descriptive qualitative data analysis. It was used to analyze the data of the study based on the results of the FGD and interviews. As illustrated in the explanation of the interactive model images developed by Sugiyono (2013), as follows:

1) Data Collection

2) Simplification of Data (Data Reduction) The data that had been collected would then be analyzed based on thematic categorization.

3) Data Presentation (Data Display) Presentation of Data was aimed at compiling information in a descriptive way

4) Conclusion Drawing,

The interpretation and the conclusion of the research were done in a deductive way based on a predetermined theoretical foundation. In this case using the 8 Policy Dimensions for the quality of health services and analyzing how these dimensions influence the successful implementation of the policy.

Research Ethics

An ethical aspect assessment of the research assessment was submitted to the ethics committee unit and to ensure there was no conflict with research ethics. After approval, ethical clearance was given. 


\section{Results and Discussions}

\section{General description}

The District of North Central Timor (TTU) was established based on Law Number 69/1958 (State Gazette of 1958 No. 122), originally called Onderafdeeling Noord Miden Timor during the Dutch Indies Government. Based on BS/Guberemen number 9-10 of 1915, Onderafdeeling Miden Timor covers a combination of three kingdoms/swapraja regions, namely the Miomaffo, Insana and Biboki Swapraja. From 1915 to 1921, the center of government administration was located in Noeltoko. In 1922, Controleur Pedemors (onder afdeeling leader) moved the center of government administration from Noeltoko to Kefamenanu. Based on the District Regulation of TTU No. 08/2007, the number of sub-districts in the TTU Regency area has become 24 sub-districts, with 174 villages. In 2015, the number of villages/kelurahan increased to 193 .

\section{Geographical situation}

Geographically, the area of the District of TTU is located between 902 '48 "SL-9 37 '36" SL and 12404 '02 "EL 12446 '00 " EL with its administrative boundaries are as follows :

- In the North: bordering to District Ambenu (Timor Leste State) and Savu Sea

- In the South: bordering to the District of TTS

- in the East: bordering to w the District of Belu

-In the West: bordering to te District of Kupang and TTS

The District of TTU is a land area of $2,669.7 \mathrm{~km}^{2}$ or it is only about $5.6 \%$ of the land area of NTT Province. While some TTU areas bordering the Savu Sea or the northern coast region consists of a sea area of $\pm 950 \mathrm{~km}^{2} \mathrm{with}$ a coastline of $50 \mathrm{~km}$.

\section{Demographic situation}

Based on the 2013 Population Registration Data, the total population in the District of TTU is 245,064 people. Then in 2017 according to the Health Service projection (based on the previous year's population), the population of the District of TTU is estimated to reach 249,711 people.

\section{Implementation of the District Health System (DHS) and various subsystems}

\section{Respondent Data}

In phase 1 of the study the respondents consisted of health workers coming from the hospital and health centers as follows:

Table 1

Distribution of Respondents based on gender in the District of TTU, 2018

\begin{tabular}{llll}
\hline No & Gender & Frequency (f) & Percentage (\%) \\
\hline 1 & Gender & 150 & \\
& Female & 158 & 72,1 \\
& Male & 58,9 \\
2 & Age & 11 & \\
& 20-25 Years & 91 & 5,2 \\
& 25-35 Years & 106 & 43,8 \\
& > 35 Years & & 51 \\
3 & Education & 10 & 4,8 \\
& < Diploma III & 146 & 70,2 \\
& Diploma III & 50 & 24 \\
& Bachelor S1/D4 & 2 & 1 \\
& Master & & \\
4 & Job Status & 43 & 20,7 \\
\hline
\end{tabular}

Minggu, D., Benu, F. L., Gana, F., \& Kase, P. (2019). Development of district health system model policy implementation for improving health services. International Research Journal of Management, IT and Social Sciences, 6(5), 242-260. https://doi.org/10.21744/irjmis.v6n5.737 


\begin{tabular}{lll}
\hline \multicolumn{1}{c}{ PTT } & & \\
Gov. Official & 10 & 4,8 \\
Duration of work & 155 & 74,5 \\
< 3 Years & 12 & 5,8 \\
3 - 5 Years & 31 & 14,9 \\
5-10 Years & 34 & 16,3 \\
> 10 Years & 131 & 63 \\
Type of workers & & \\
Specialist & 4 & 1.92 \\
General Practioner & 12 & 5.77 \\
Dentist & 11 & 5.29 \\
Nurse & 59 & 28.37 \\
Midwife & 51 & 24.52 \\
Pharmacist & 10 & 4.81 \\
Nutritionist & 10 & 4.81 \\
Public Health & 11 & 5.29 \\
Sanitarian & 10 & 4.81 \\
Admin & 10 & 4.81 \\
Other health background & 10 & 4.81 \\
Non-Health staff & 10 & 4.81 \\
Total & 208 & 100 \\
\hline
\end{tabular}

The data in Table 1 shows the characteristic of the respondents in which the majority of respondents were women (150 or $72.1 \%$ ), based on age, age > 25 years were 197 people $(94.8 \%)$. Most of the respondents-146 people (70.2\%) had Diploma III background and totaling 165 people $(79.3 \%)$ were holding civil servants status (PNS) with a period of work of $>5$ years.

The implementation of the District Health System was found in the results of the Focus Group Discussion and brainstorming on August 28th , 2018 and In-depth Interviews on August 29ht and 30th with total respondents of 19 people consisting of 9 people from the Health Service and 10 people from the other related Sectors (Health Office include: (KADINKES / Secretary, Head of PPSM \& PL, Kasie Promkes, Head of PDE, Head of Puskesmas: 4 people, Pharmacy Warehouse, UPK Field Health Office Staff, Hospital Staff): In-depth interview 10 health-related SKPD leaders.

The influence of interconnection and interaction between DHS's subsystems that influence health services in TTU District, NTT Province

The Structural Equation Modeling process was done with Amos 20.0. Parameter estimation could be identified after the model could be assessed by structural tests which could be identified by Amos. (1) Significance tests were carried out by determining if the parameters produced were significantly different from zero. Next step was the fit model assessment (Archana et al., 2016; Mardika, 2017). A model is said to be fit if the covariance matrix of a model (model-based covariance matrix) was proved the same as the covariance matrix data (observed). Model fit was obtained from Amos, for example RMSEA, RMR, GFI, CFI, TLI, NFI (2) Modify the model to get a fit model. (3) Crossvalidation of the model as the final stage - testing whether or not the model was fit against new data.

The results of the normality scale data analysis of the proportions of all indicators (univariate and multivariate) showed that the data distribution did not meet the assumption of normal distribution at a significance level of 0.01 ($2.58 \leq \mathrm{cr} \leq+2.58$ ), as Ghozali (2017), it is explained that the structural equation model analysis of data that has an abnormal multivariate distribution would cause an increase in the value of chi-square. The results of the analysis found an improper solution to the model being tested, the parameters of the suitability of the model underestimate, and produces standard error estimates (standard errors) that tend to be low, so the paths (variants and covariants) in the model being tested will be significant even though it is not significant in the population. One way to analyze data with abnormal multivariate distribution suggested by Ghozali (2017), is the Bollen-Stine Bootstrap technique in Amos software. 


\section{Suitability of Hypothetic Model}

The results of the analysis on the suitability of the hypothetical model demonstrated that the model has not met the criteria of a good model (model fit). According to Ghozali (2017), one of the steps that can be made to a rejected model (an unsuitable model) by modifying the model following Modification Indices output from the Amos 20 software. The modification application of the model has resulted in the suitability parameters of the model that meet the criteria of model compatibility, as in Table 2.

Table 2

Model suitability parameters that meet the model matching criteria

\begin{tabular}{llll}
\hline Parameter & Criterium & $\begin{array}{l}\text { The Result of } \\
\text { Analysis }\end{array}$ & Conclusion \\
\hline Chi Square probability & $\geq 0,05$ & 0,111 & Model Fit \\
Cmin/df & $\leq 2,00$ & 1,158 & Model Fit \\
GFI (Goodness of Fit) & $\geq 0.85$ & 0,940 & Model Fit \\
AGFI (Adjust Goodness of Fit Index) & $\geq 0.85$ & 0,897 & Model Fit \\
TLI (Tucker-Lewis Index) & $\geq 0.90$ & 0,991 & Model Fit \\
NFI (Normated Fit Index) & $\geq 0.80$ & 0,959 & Model Fit \\
CFI (Comparative Fit Index) & $\geq 0.90$ & 0,994 & Model Fit \\
RMSEA (Root Mean Square error of Approximation) & $\leq 0.08$ & 0,028 & Model Fit \\
\hline
\end{tabular}

Development of the Model "Implementation of the District of TTU Health System Policy" with a Chisquare value of $0.111>0.05$ did not significantly indicate that the empirical data obtained was fitting to the model. Chi-Square value is very sensitive to the size of the sample. CMIN / DF value 1.158 is chi-square value divided by degree of freedom. This value $<2$ is a fit size. The goodness of Fit Index (GFI) of $0.940>0.85$ indicates the fit of a good model. A GFI of 1 means that the model has a perfect fit. Similar to GFI, the Adjusted Goodness of Fit Index (AGFI) has adjusted to the influence of degrees of freedom on a model, this model is fit. Because the value of AGFI (0.897), the model is fit. As in the study the value of NFI was 0.959 , it is said to be a fit model. TLI value of $0.991>0.90$ indicates a fit model. Normed Fit Index (NFI) value of 0.959 indicates this model is fit. CFI value of 0.994 indicates a fit model. Comparative Fit Index (CFI) value = 0.994 greater than 0.9 indicates that the model is fit (Bentler, 1990). Root Mean Square Error of Approximation (RMSEA) 0.028 indicates the model is quite reasonable and does not belong to the "rejection" category of Browne \& Cudeck (1993), Byrne \& Russon (1998). This RMSEA is the most informative model fit indicator. RMSEA measures the deviation of parameter values in a model with its population covariance matrix (Browne \& Cudeck, 1993).

In this research, the number of samples has fulfilled -the "Rule of Thumb" - with 4 latent variables and 2 independent variables. There were 20 observed indicators/variables, the required sample was 5-10 per each indicator so that the total sample needed is 200 - 400 respondents. In this research the total sample was of 208 respondents - the minimum requirements needed in the study as well as the scale of data in this research was continuous interval which was normally distributed.

Application of Bollen-Stine Bootstrap technique in Amos 20.0 software was applied in analyzing structural equation models in the study (Appendix 2 Bollen Stine Bootstrap). Bootstrapping is a sampling procedure where the original sample will be treated as a population. Multiple subsamples with the same sample size as the original sample were then taken randomly with replacement from the population (Nahak, 2017; Paramita et al., 2018). The researcher could create multiple samples from the original database. The Bolle-Stine Bootsrap can evaluate the suitability of the hypothesized model, testing the null hypothesis that the model specification was correct. The analysis demonstrated better chi-square parameter values, and it was concluded that the hypothetical model tested was acceptable (model fit): the selected indicators matched and represented the variables, with the outputs in Table 3 as follows:

Minggu, D., Benu, F. L., Gana, F., \& Kase, P. (2019). Development of district health system model policy implementation for improving health services. International Research Journal of Management, IT and Social Sciences, 6(5), 242-260. https://doi.org/10.21744/irjmis.v6n5.737 
Table 3

Results of Analysis of Structural Equation Models using Amos 20.0 software with the Bollen-Stine Bootstrap Technique

\begin{tabular}{llll}
\hline Data and Analysis Technic & $\begin{array}{l}\text { Chi-square } \\
\text { Value }\end{array}$ & $\mathrm{p}$ & Conclusion \\
\hline Data Proportion & 584,232 & 0,000000 & $\mathrm{p}<0,05$ (not significant) \\
Data Proportion - Arcsin & 571,148 & 0,000000 & $\mathrm{p}<0,05$ (not significant) \\
Modification of Model with Data Proportion - & 125,625 & 0,073000 & $\mathrm{p}>0,05$ (significant) \\
Arcsin & & & \\
Bollen-Stine Bootstrap Technic (500 bootstraping) & 273,781 & 0,090909 & $\mathrm{p}>0,05$ (significant) \\
\hline
\end{tabular}

Table 3 modification of the model with Arcsin data can conclude the empirical data, it shows the suitability of the hypothetical model, and therefore the model becomes an empirical model.

Interpretation of Regression and Correlation Analysis Results

The results of the regression analysis and correlation between variance and covariance hypothesized in the model were presented in Appendix 2 (Estimates - Regression and Correlation). The results of the analysis show that:

a) All indicators measured had a significant influence on each contract measured, which means that these indicators were significantly used in measuring the construct.

b) There was a partially significant influence between the District Health System (DHS) and Responsiveness (RPS) on Policy Implementation (PI)

c) There was a significant simultaneous influence between the District Health System (DHS) and Responsiveness (RPS) on Policy Implementation (PI)

d) There was a significant influence between Policy Implementation and Health Services (HS)

The table of regression weights (predictor constants) was standardized and the correlation weights presented below show that:

a) Policy implementation had a stronger correlation with Responsiveness (0.84) compared to the District Health System, but the District Health System had a greater multiplier influence than Responsiveness as indicated by the presence of predictor constants of 0.7839 and 0.2012 , respectively.

b) The policy implementation had a strong correlation $(r=0.64)$ with Health Services, with a predictor constant of 0.7859

c) The seven indicators of the construct of the District Health System (MI, PBM, LIT, SFAM, PB, HR, and UPK) had a significant relationship with the construct, with a correlation coefficient between 0.5312 to $0.7590(0.5312$ $\leq \mathrm{r} \leq 0.7590)$, with a large regression weight $(0.6590-0.8999)$

d) Two indicators of construct responsiveness (RPS1 and RPS2) had a significant relationship with the construct, with correlation coefficients respectively of 0.4091 and $0.6773(0.4091 \leq \mathrm{r} \leq 0.6773)$, with large regression weights (respectively amounted to 0.6390 and 0.9333 )

e) Three indicators of the construct of Health Services (HS1, HS2, and HS3) have a significant relationship with the construct, with a correlation coefficient between 0.4083 to $0.8711(0.4083 \leq \mathrm{r} \leq 0.8711)$, with a regression weight between 0.6400 to 0,8230 .

f) The eight indicators of the construct of Policy Implementation (PI1 to PI8) had a significant relationship with the construct, with a correlation coefficient between 0.4343 to $0.8488(0.4343 \leq \mathrm{r} \leq 0.8488)$, with a large regression weight $(0.6396-0.8999)$.

Table 3 modification of the model with Arcsin data can conclude empirical data showing the suitability of the hypothetical model so that the model becomes an empirical model

The conclusions from the results of the analysis above are:

a. All indicators measured in this study are empirically appropriate indicators for measuring the variables (constructs) that exist in the tested model.

b. The District Health System has a stronger influence on Policy Implementation than Responsiveness, and subsequently, Policy Implementation has a strong influence on Health Services. 
In this study there was a partially significant influence between the District Health System (DHS) and Responsiveness (RPS) on the Policy Implementation (PI) and there was a significant simultaneous influence between the District Health System (DHS) and Responsiveness (RPS) on the Policy Implementation ( PI). It explains that the District Health System which consists of 7 (seven sub-systems): Information management and health regulation, health financing, health human resources, health efforts, pharmaceutical preparations, medical devices and food, health research and development, empowerment and community participation in an integrated manner Responsiveness dimensions which covers hospitality, physical building, adequate equipment, comfort, personality, privacy, waiting times for skilled and competent officers, performance of officers and management, SOP, service environment and improvements in efficiency and fairness, partially or co-exist giving same influence on policy implementation. In a system framework, implementation is a process of conversion (throughput) that converts inputs (policies, objectives and their facilities converted into outputs and outcomes). Policy implementation covers standards of policy and objectives, resources, relationships between organizations, characteristics of implementing agencies, socio-economic conditions, implementor dispositions, communication, and bureaucratic structure, They are very lPIely the same policies that are interpreted and implemented differently by implementing actors in different regions so the results won't be the same. For example, policies originating from the central government, but being implemented by regional governments are very 1PIely depending on the policies of each district head, thus, the results of their implementation will also vary. Thus, the capabilities/capabilities, interests, and perceptions of district actors greatly influence the results of implementation.

District Health System Regulation of TTU No. 9 of 2015 has been implemented in TTU District requiring health financing to be at least $10 \%$ of the total APBD excluding yearly salary (District Regulation on DHS No. 9 of 2015 article 156 paragraph 2). The implementation of health sector financing $>10$ percent have been implemented. But there are still a lot of requirements have not been carried properly and this was revealed in the in-depth interviews.

Georges Edward III (1980), explained that the main problem of public administration is "lack of attention to implementation. It was explained that without influence implementation, the decision of policymakers would not be executed successfully. Edward suggested paying attention to 4 main issues in order the implementation of a policy will be influenced, namely: communication, availability of resources, disposition and bureaucratic structure. The results of the study indicate that the DHS policies have been communicated through public consultations and related crosssectoral meeting activities: the availability of resources to execute policies, attitudes, and responsiveness to the parties involved as well as the organizational structure in implementing the policies. This policy should also be supported by competent human resources where the District of TTU continues to improve for the fulfillment of competent human resources in the health sector. The willingness of the implementors to implement policies stipulated in the DHS Regulation of TTU, as well as the suitability of the organizations that organize the implementation of public policies. The DHS Regulation was made based on an initiative from the Executive of the TTU District Health Office who understood in detail the problems in the health sector.

The results of this study are fit in with the model developed by Donald Van Meter \& Carl van Horn (1975) who rely on that policy implementation runs linearly from public policy, implementors and public policy performance. Variables that influence policy include policy standards and targets, policy performance, resources, relationships between organizations, characteristics of implementing agencies, socio-political and economic conditions, and implementor dispositions. The successful implementation of the DHS policy in accordance with what was stated by Van Meter \& van Horn (1975), namely (1) the policy objectives and the DHS standards are clear - the breakdown of targets to be achieved through policies and standards to measure their achievement, (2) resources ( funds and various incentives that can facilitate the influence of implementation, (3) the quality of inter-organizational relations. Successful implementation requires procedures and institutional mechanisms that allow a higher structure to control, thus, the implementation runs in accordance with established goals and standards, (4) Characteristics of institutions/implementing organizations (including the competence and size of implementing agencies, the level of hierarchical control - there was the lowest implementing unit at the time of implementation, political support from the executive and legislative, and formal and informal links with policy-making bodies, etc.) (5) Political, social and economy (ensure there is sufficient economic power; how far and how the policy can influence the existing socioeconomic conditions; How the government's response to the policy; does the elite support implementation? etc). (6) Disposition/response or attitude of the implementers, including knowledge and understanding of the contents and objectives of the policy, their attitude to the policy and the intensity of the attitude. In this study, the Government strongly supports the adoption of DHS Regulation No. 92015.

Minggu, D., Benu, F. L., Gana, F., \& Kase, P. (2019). Development of district health system model policy implementation for improving health services. International Research Journal of Management, IT and Social Sciences, 6(5), 242-260. https://doi.org/10.21744/irjmis.v6n5.737 
Dachi RA (2017), explained that there were 3 (three) essential components in the interconnected health system, namely health policy itself, actors of policy environment of policy, all three are known as the policy triangle. Policymakers - the Government and the Parliaments (DPR / DPD / DPRD) which are the elements related to the process of the birth of health policy. The policy environment is the state/condition of health that underlies a health policy. Health policy is the product of choice for the government to solve existing health problems. Health policy refers to the District Health System Regulation (District Health System Regulation of TTU). This health policy in its implementation comprehensively targeted people who had enrolled in the policy process. In this study, DHS as public policy has gone through a structured process starting from the identification of problems to the issuance of the DHS of TTU Regulation No. 9/2015.

In this study, there was a significant influence between the implementation of policies (PI) and health services. The concept of WHO (2000) in Ratu Ludji (2014), it was explained that the function of the health system in relation to outcomes related to Health System Performance includes Equity (fairness), access, Quality, Efficiency and Sustainability (WHO), WHO 2009; 31 and WHO 2010; vii (The Building Blocks of Health System; Aim and Attributes indicate that health building blocks consist of (1) Service Delivery; 2) Human Resources Health / health workers (Health Workforce), (3) Health information systems, (4) Medical Products, Vaccines \& Technologies, (5) Financing (6) Leadership and Governance. The six blocks of the system provide access coverage (Quality Coverage) and quality assurance (Quality Safety) to achieve general goals, namely: (1) Improve health status (Improved Health; Level and Equity); (2) Responsiveness; (3) Social and Financial Risk Protection; (4) Improved Efficiency. Coordination and dynamic interrelationships of the health system.

The dynamic linkages of the health system place people at the focal point of all sub-systems where their roles are very important to underline, not only at the center of the system as a mediator and beneficiary but as an actor in encouraging and controlling the system itself. This includes those who participate either as individuals, members of civil society, organizations, and stakeholder networks, or the key roles as actors that influence the system - health human resources, managers and policymakers, service providers. Placing the people and all institutions at the center of this framework emphasizes WHO to renew its commitment to the principles and values of primary health care wich empathize on fairness and equitable, socially equitable, participation and collaboration across sectors (WHO, 2009).

In this study, policy implementation also had a strong correlation with responsiveness. This was because of one stage of the health policy process was mapped from the dimensions of successful policy implementation including access and responsiveness (Dachi, RA p. 132). Responsiveness is "Willingness to help customers and provide prompt service" is a process-oriented measure and results of concern to the customer/client.

Policy implementation has a strong correlation with health services because health services include coverage and access, health improvements (refers to level and equity) and protection of social and financial risks and fair are 3 (three) important things that have been a concern in policy implementation. Ayuningtias (2018), explained that the Ministry of Health has rolled out seven health development reforms and one of the important things that had been put into first priority was the revitalization of health services. 2) availability, distribution, retention, and quality of human resources 3) Availability, distribution, safety, quality, influence, affordability of drugs, vaccines, and medical devices. 4) health insurance 5) alignments to disadvantaged areas, borders and islands (DTPK) and health problem areas (DBK) 6) bureaucratic reform and 7) World-class health care. In the health services efforts, community-based health services were prioritized by emphasizing promotive and preventive efforts. Health care provider does not wait for people to fall ill, because it will cost a lot.

The District Health System (DHS) with its seven sub-systems has a significant relationship with its constructs/variables. The implementation of the TTU district DHS requires inter-system linkages as an influence relationship system. The information management and health regulation sub-system were organized to produce health policy functions, health administration, planning, budgeting, implementation, supervision and evaluation, data and information management, health information, and adequate health law and being able to support the implementation of health efforts successfully and efficiently. With good health management, implementation of health human resource subsystems, pharmaceutical preparation subsystems, medical devices and food, health research and development subsystems, community empowerment and participation subsystems and partnerships, health financing subsystems, and health effort subsystems as an integrated unit in efforts to improve the highest degree of public health (Ratu Ludji, 2014).

District Health System (DHS) of the District of TTU is a form and procedure for the implementation of health development in the District of TTU that is carried out by all components of the Indonesian people, particularly the people of TTU in an integrated and comprehensive manner. It always adheres to the principles and systems as the basis for all health development programs and activities to ensure the highest health status of the people of TTU. In practice, 
the strategic position of health sector has been in the stream of political issues. An example of the political influence on the health policy can be found in Law No. 32 of 2004 concerning decentralization. Health as one of the decentralized authorities, as at national level there has been NHS, while in districts, there are DHS. Thus, the goal of decentralization is to make health services more efficient and effective, create better services to the community (aspirational, accommodative and responsive), as well as increasing opportunities for participation and democracy in the health sector (Ayuningtias, 2019).

Development of District Health System implementation models that influence health services in TTU District, NTT Province

Direct influences, indirect influences (via intermediate variables) and total influences (direct and indirect) between variables hypothesized in this study are presented in Table 4.

Standardized direct influences which are a measure of the strength of influence between a variable with other variables - directly connected (variant relationship path) in this study are: This conceptual model was analyzed with AMOS 20.0 and the next step was to conduct SEM analysis using Observed variables and latent variables, where the results are as in Figure 2 The model is modified as shown in Figure 3.



Figure 2. The model with Latent Variable and Indicators

Figures 2 and 3 demonstrate that the observed variables/indicators that formed endogenous/dependent latent variables are Health Services and Policy Implementation. Endogenous latent variables refer the Policy Implementation formed by the observed variables, namely policy standards and targets, resources, relationships between organizations, institutional/organizational characteristics, social, economic and political conditions, implementor dispositions, communication, and bureaucratic structures. Latent variables - health services - were formed by observed variables, namely access, coverage, health improvement (level and equity), improved health (level and equity), social financial risk protection and fairly)

Exogenous/independent latent variables- Responsiveness- was formed by 2 (two) observed variables/indicators, namely: (1) Response - including hospitality, physical building, adequate equipment, comfort, personality, privacy, waiting time, skilled and competent officers, the appearance of officers and management, there are SOPs, cleanliness of the service environment, (2) Improvements in efficiency and fairness (Improved Efficiency and Fairness). Exogenous latent variables / independent Regional Health System was formed by 7 (seven) observed variables - Information Management and Health Regulation, Human Resources, financing, pharmaceutical preparations and medical devices, health service efforts, health

Minggu, D., Benu, F. L., Gana, F., \& Kase, P. (2019). Development of district health system model policy implementation for improving health services. International Research Journal of Management, IT and Social Sciences, 6(5), 242-260. https://doi.org/10.21744/irjmis.v6n5.737 


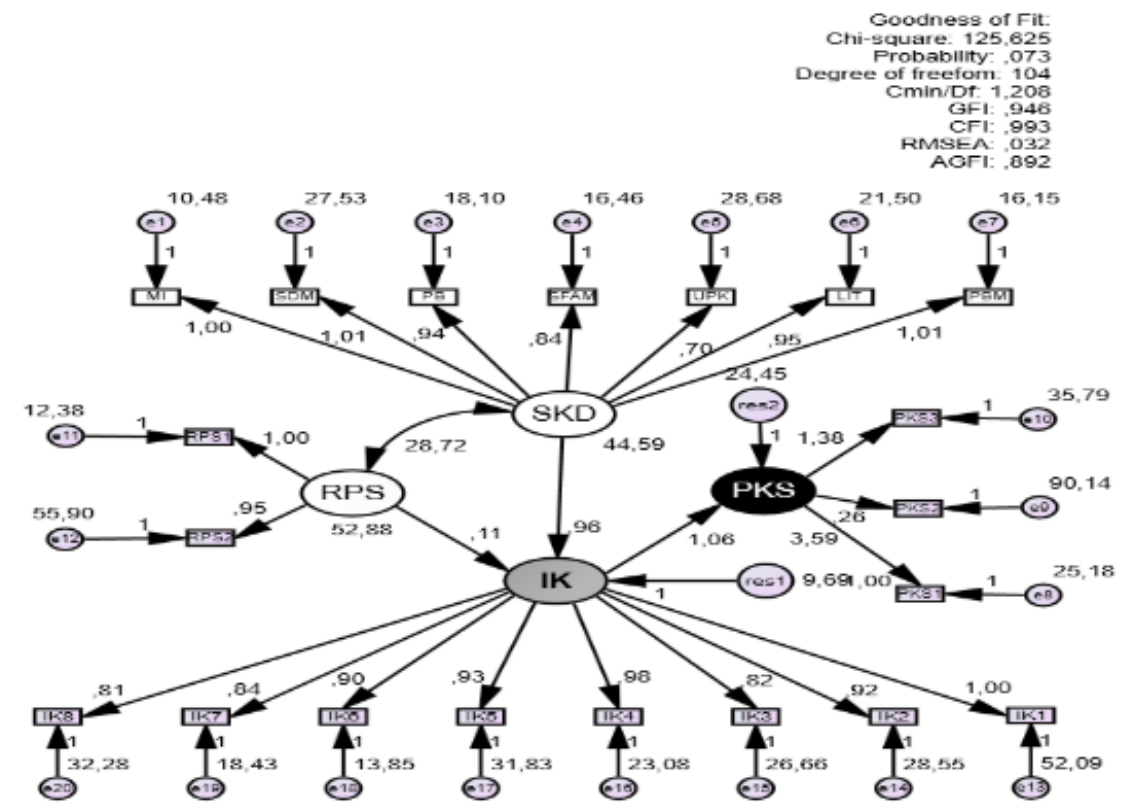

research and development and community empowerment.

Remark

$\begin{aligned} \rightarrow & =\text { Meaningfull influence } \\ & =\text { No meaningful influence }\end{aligned}$

Figure 3. Modifying Model with Latent Variable and Indicator

In the original model without bootstrapping in Figure 2 shows a chi-square value of 571,148 with a probability of 0,000. In Figure 3, the mean, Chi-square, and chi-square distribution values with the Bollenine bootstrap 500 samples are 273.78 with the chi-square value of 125.625 with probability $=0.073$ and this value was not significant at $\alpha=0.05$ which stated that the model cannot be rejected or the model is good. Chi-square 273.78 obtained from boostrap shows cluster values in the normal multivariate center 273 and the distribution of chi-square values were normal because there were several values above and below 273 that were comparable. The results of the development of the district health system implementation model in TTU district are simply described in Table 4, as follows:

Table 4

Development of Approach Model "Implementation of the District Health System in the District of Timor Tengah Utara (TTU), East Nusa Tenggara Province NTT

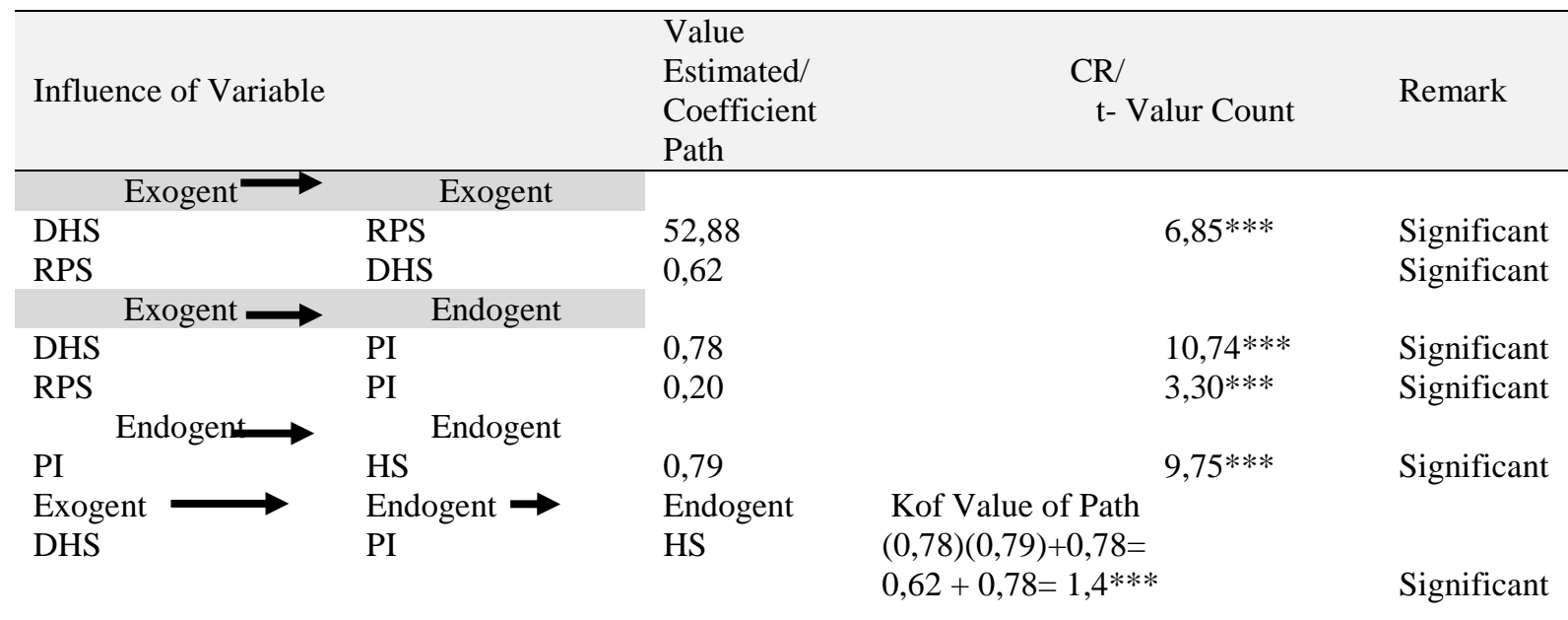




\begin{tabular}{|c|c|c|c|c|}
\hline RPS & PI & HS & $\begin{array}{l}(0,20)(0,79)+0,20= \\
0,16+0,20=0,36^{* * *}\end{array}$ & Significant \\
\hline Exogent & Exogent & Endogent & & \\
\hline DHS & RPS & PI & $\begin{array}{l}(52,88)(0,20)+0,78= \\
10,58+0,78=11,36^{* * *}\end{array}$ & Significant \\
\hline RPS & DHS & PI & $\begin{array}{l}(0,62)(0,78)+0,20= \\
0,48+0,20=0,68 * * *\end{array}$ & Significant \\
\hline $\begin{array}{l}\text { Exogent } \\
\text { DHS }\end{array}$ & $\begin{array}{l}\text { Exogent } \\
\text { RPS }\end{array}$ & $\begin{array}{l}\text { Endogent } \\
\text { PI }\end{array}$ & $\begin{array}{l}\text { Endogent } \\
\text { HS } \\
(52,88)(0,20)(0,79)=8,36^{* * * *}\end{array}$ & Significant \\
\hline RPS & DHS & PI & $\begin{array}{l}\text { HS } \\
(0,62)(0,78)(0,79)=0,38 * * *\end{array}$ & Significant \\
\hline
\end{tabular}

Remark: *** Significant on 0,001

Table 4 explains that there are 2 exogenous variables in the District Health System (DHS) and Responsiveness (RPS) as well as 2 endogenous variables in Health Services (HS) and Policy Implementation (PI). Variables with the greatest influence $>65 \%$ directly or indirectly influenced the Implementation of Health Policy and Services:

1) Influence of District Health System (DHS) variable on Responsiveness (RPS); The District Health System (DHS) had a positive influence on Responsiveness (RPS) with a standardized coefficient of 52.88, meaning that the implementation of the District Health System (DHS) increased Responsiveness by 528\%. Instead, Responsiveness (RPS) would increase the implementation of the District Health System (DHS) by $62 \%$.

2) The District Health System (DHS) has a positive influence on Policy Implementation (PI) with a standardized coefficient of 0.78 meaning that DHS Implementation would increase Policy Implementation (PI) by $78 \%$.

3) Policy Implementation (PI) had a positive influence on Health Services (HS) with a standardized coefficient of 0.79 meaning that Policy Implementation (PI) would increase Health Services (HS) by $78 \%$.

4) The District Health System (DHS) had a positive influence on Health Services (HS) through Policy Implementation (PI) with a standardized coefficient of 1.4 meaning that the District Health System (DHS) through Policy Implementation (PI) would increase Health Services (HS) by $140 \%$.

5) The District Health System (DHS) has a positive influence on Policy Implementation (PI) through Responsiveness (RPS) with a standardized coefficient of 11.36, meaning that the District Health System (DHS) through Responsiveness (RPS) would increase Policy Implementation (PI) by $1136 \%$.

6) Responsiveness (RPS) had a positive influence on policy implementation (PI) through the District Health System (DHS) with a standardized coefficient of 0.68, meaning that Responsiveness (RPS) through the District Health System (DHS) would increase Policy Implementation (PI) by $68 \%$.

7) The District Health System (DHS) through Responsiveness (RPS) and Policy Implementation (PI) had a positive influence on Health Services (HS) with a standardized coefficient of 8.36, meaning that the District Health System through Responsiveness (RPS) and Policy Implementation (PI) would improve Health Services (HS) by $836 \%$.

New Model of "Development of Dominic BGF District Health System Implementation Model for Improving Health Services in Central Timor Regency, North East Nusa Tenggara Province

Development of District Health System Policy Implementation Model Dominic BGK in TTU Regency, East Nusa Tenggara "was made by 4 main variables, namely: District Health System (DHS), Responsiveness (RPS), Policy Implementation (PI) and Health Services (HS)

1) The District Health System (DHS) consists of 7 (seven) indicators, namely: (1) information management and health regulation, (2) health human resources, (3) health financing, (4) pharmaceutical preparations, medical devices, food and beverage, (5) Health efforts (6) Health research and development and community empowerment and participation.

2) Responsiveness (RPS) consists of 2 indicators: (1) Responses include hospitality, physical building, adequate equipment, comfort, personality, privacy, waiting time, skilled and competent officers, staff appearance and management, SOP, sanitation of the service environment and (2) Improvements in efficiency and fairness (Improved Efficiency and Fairly).

Minggu, D., Benu, F. L., Gana, F., \& Kase, P. (2019). Development of district health system model policy implementation for improving health services. International Research Journal of Management, IT and Social Sciences, 6(5), 242-260. https://doi.org/10.21744/irjmis.v6n5.737 
3) Policy Implementation (PI) consists of 8 indicators, namely: (1) Policy Standards and Targets, (2) Resources, (3) Inter-Organizational Relations, (4) Characteristics of Implementing Agencies, (5) Socio-Economic and Political Conditions, (6) Disposition of Implementers (7) Communication and (8) Bureaucratic Structure.

4) Health Services (HS) consists of 3 (three) indicators, namely: (1) Coverage of access (2) Improved Health Level and Equity / Health improvement; level and equity (3) Social Financial Risk Protection and Fairly (Protection of financial and fair social risks)

The most dominant variables were District Health System (DHS) through Responsiveness (RPS) would increase Policy Implementation (PI) by 1136\%; The District Health System (DHS) through Responsiveness (RPS) and Policy Implementation (PI) would increase Health Services (HS) by $836 \%$. the implementation of the District Health System (DHS) would increase Responsiveness by 528\%. The District Health System (DHS) through Policy Implementation (PI) would increase Health Services (HS) by 140\%. Policy Implementation (PI) would increase Health Services (HS) by $79 \%$. The DHS implementation would increase the Policy Implementation (PI) by 78\%. Responsiveness (RPS) through the District Health System (DHS) would increase Policy Implementation (PI) by $68 \%$.

The novelty of this research was formed by several theoretical concepts - Model of policy theory from Edward III (1980), Van Meter \& Van Horn (2015); Health System FrameWork (WHO, 2010); The Dynamic Architecture and Interconnectedness of the Health System Building Blocks (WHO, 2009); The Dahlgreen and Whiteheads Theory Concept (1991) "Social Determinants of Health Rainbow" Social-Ecological Models of Health Behavior: Moore J (2003) Moore J (2003); National Health System (2012) and the DHS of TTU District (2015). As shown in Figure 4

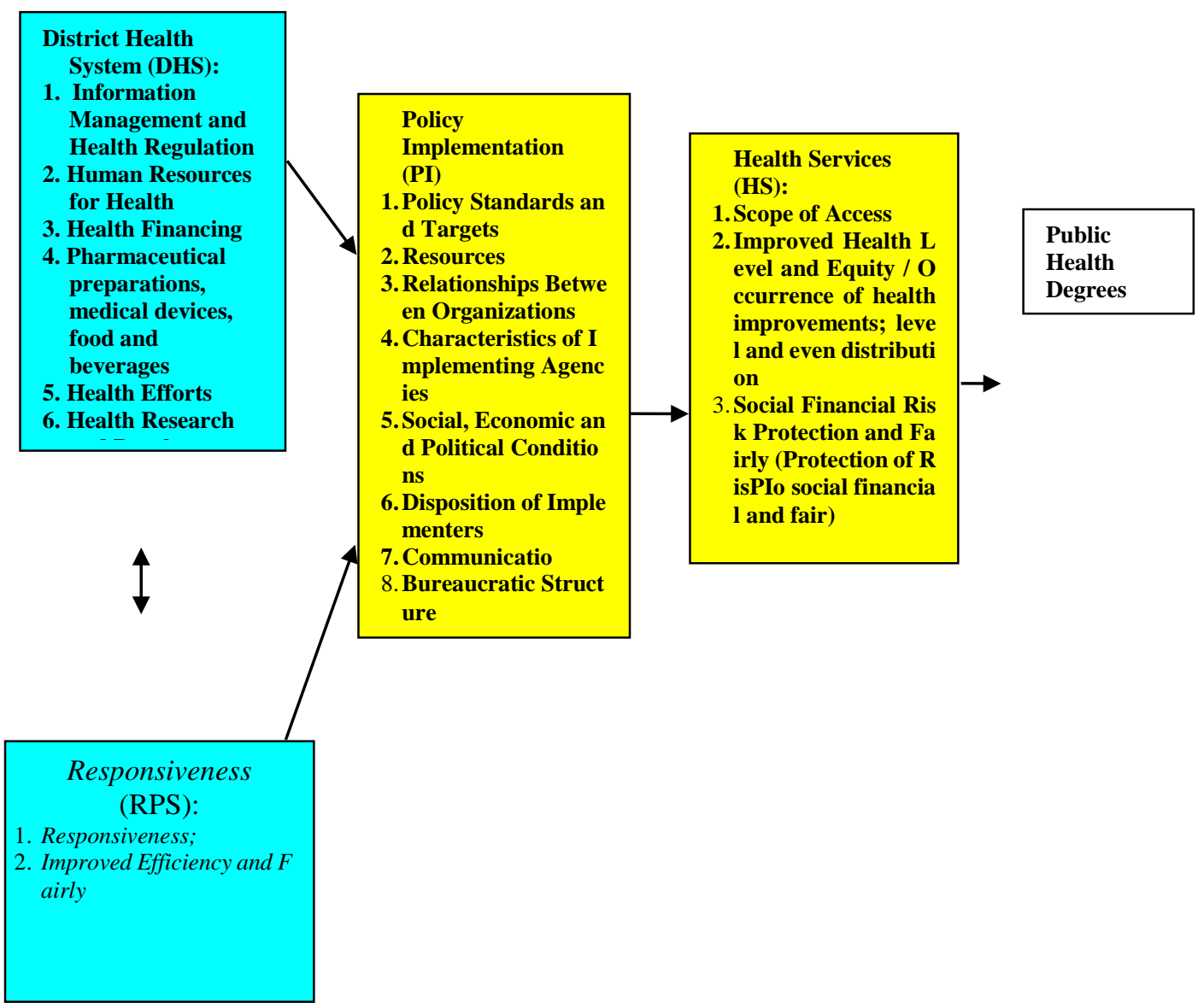

Figure 4. Development of the Model "Implementation of District Health System Policy" Dominic BGK "in the District of TTU, NTT Province 


\title{
The Result of Indepth Interview on the Implementation of the District Health System in TTU District
}

\section{Policy Implementation}

Policy implementation is an important aspect of the entire policy process. Donald Van Meter and Carl van Horn in Herabudin 2019) define policy implementation as:

\begin{abstract}
“...policy implementation encompasses those action by government and privat individuals (or group) that are directed at the achievement of objectives set forth in the prior policy decisions. This includes both one-tome effort to transform decision into operational terms, as well as continuing efforts to achieve the large and small changes mandated by policy decisions"
\end{abstract}

That the implementation of the policy is an action taken by the government and private (organization, either) individually or as a group which is intended to achieve certain objectives.

Policy implementation is a strategic stage following the formulation and/or design process. At the level of the process, it has been going well and produced District Regulation No. 92015 as joint legal products initiated by the executive side - Health District Office of TTU. This was presented by 3 KC Participants:

"During the discussion on the DHS Regulation, the members of the legislative body and the chairman of commission $\mathrm{B}$ were also present where a participatory process happened:

- There had been consultation meeting of stakeholders, NGOs (for aspiration )

- The process was drafted by a team consisted of Dr. Ina Debora - Health Consultant, Yunus Bureni, and Dr. John Kotan - Legal Consultants facilitated by the "AIPHSS"

- The Draft was, then sent to the Legislation Board (for assistance)

- Participatory District Regulations "

At this level of implementation, a policy would be tested its substantive and in terms of effectiveness in its use. There were three sets of policy implementation in government policy analysis that needed to be understood, namely policy formulation, policy implementation, and policy evaluation.

In the level of the process, The regulation of District Health System of TTU had been on the right track and process in accordance with regulations - tracking down the district policies encompassed general policies and implementation policies. 1) General policy in the district context was the district government represent the implementation of decentralization having obligation to manage all affairs at district level -as single authority to establish general policies in the area. In the Regional level - district/city. the general policy is determined by the head of district/mayor and district/city parliament (DPRD). General policies at the regional level can be in the form of Provincial Regulations (PERDA) and District/Municipal Regulation as in the case of DHS Regulation No. 9 2015. 2) Implementation policies at the district level consisted of three main things: (1) Implementation policies in the -decentralization framework of the implementation of the DHS Regulation No. 9 2015; (2) Implementation policy in the context of deconcentration is the implementation of national policies in the regions; (3) The implementation policy in the context of coadministration (medebewind) is the implementation of the tasks of the central government in regions organized by the district governments. The authority to determine implementation policies at the District level in the context of decentralization, deconcentration, and co-administration is the governor/regent/ mayor.

Policy implementation connects the policy objectives and their realization with the results of government activities. This is in accordance with the view of Van Meter and van Horn (Grindle, 1980), explaining that the task of implementation is to build a network that enables public policy objectives to be implemented through the activities of government agencies involving various interested parties. Wahab (2001) explains that policy implementation can be seen from several points of view, as follows:

1) The main concern of policymakers is to focus on "the extent to which the policy has been reached and what are the reasons that led to the success of the policy or the failure of the policy". The implementation of the TTD district DHS policy has been achieved in line with expectations. Although in its implementation it has been acknowledged that it has not been carried out widely and optimally because it is constrained by costs so it requires the involvement of external parties (NGOs). This is in accordance with what was delivered by Participant 5 (DDR) and Participants 6 (DRS).

Minggu, D., Benu, F. L., Gana, F., \& Kase, P. (2019). Development of district health system model policy implementation for improving health services. International Research Journal of Management, IT and Social Sciences, 6(5), 242-260. https://doi.org/10.21744/irjmis.v6n5.737 
"Implementation of DHS District Regulations is still a lot of obstacles. Socialization has not been maximized. There needs to be involvement of external parties (NGOs) (DDR).

"The existing DHS regulation is already good, and it has been implemented, however, there has been no official dissemination yet. Need official socialization (DRS).

2) From the implementor's perspective, implementation is focused on "the actions of officials and agencies in the field to convey programs success". This has been done but not maximally. Dissemination of the regulation to related officials and agencies in the field have not been done. The implementation was mainly focused on $\mathrm{MCH}$ and women's reproductive health, including policies to assist victims of gender-responsive violence. Funding has been a great concern of all participants, as stated by Participants 2 (KC)

"At the implementation level, the focus is just on women's reproduction. In hospitals, for particular cases related to victims of female violence, the post mortem examination is free. ... There has been a policy in place to assist victims of violence. ... Regarding the implementation of the DHS Regulation, funding has been the concern, its implementation is currently being considered ".

3) From the point of view of the target group, implementation will focus more on "whether the implementation of the policy has really changed its lifestyle and has a long positive impact on improving the quality of life including their income". At this stage, implementation has been carried out on the target population that can have a positive impact, namely "Women" that are gender-responsive. Providing protection and assistance to victims of violence, considering that TTU district is the outermost district and is located in a border area. This was stated by Participant 2 (KC) in point 2).

Implementation according to Edwards, is defined as a stage in the policy process that is between the stages of the preparation of the policy and the results or consequences caused by that policy (output, outcome). There are four critical factors that influence the success or failure of implementation. The approach taken is to ask the question, "What preconditions must exist for successful implementation?" And "What are the main obstacles to the success of an implementation?". The four factors are 1) communication. 2) resources. 3) disposition or attitude of implementers. 4) bureaucratic structure, all of which are interconnected and influence each other in determining the success or failure of implementation.

\section{Research Limitations}

This research was conducted on quantitatively and qualitatively. In quantitative research the conceptual model was prepared with many indicators. Because of the limited number of samples studied could be overcome by combining several indicators on Health Services and Responsiveness combined analysis, thus, it met the criteria for the number of "rule of thumb" for statistical analysis. Weaknesses in quantitative research were complemented by qualitative research so that the discussion was completed in accordance with the expected research objectives.

\section{Conclusion}

a) Both the District Health System (DHS) and Responsiveness (RPS) directly influenced Policy Implementation (PI)

b) Both the District Health System (DHS) and Responsiveness (RPS) indirectly influenced Health Services (HS) through Policy Implementation (PI)

c) The District Health System (DHS) Influenced Responsiveness (RPS) and Health Services (HS) through Policy Implementation (PI)

d) Responsiveness (RPS) directly influenced the District Health System (DHS), thus, the District Health System (DHS) influenced the Implementation of Policies and the Implementation of Policies (PI) influences Health Services (HS)

e) The District Health System (DHS) directly influenced Responsiveness (RPS), thus Responsiveness (RPS) influenced Policy Implementation and Policy Implementation (PI) influences Health Services (HS)

f) Policy Implementation (PI) directly influenced Health Services (HS)

g) Policy Implementation Model with indicators - policy standards and targets, resources, relationships between organizations, characteristics of implementing agencies, socio-economic and political conditions, implementor 
disposition, communication, and bureaucratic structure) were directly influenced by 1) District Health System (DHS) with its subsystem information management and health regulation, financing, health human resources, health efforts, pharmaceutical preparations for food and beverage, health equipment, health research and development and community empowerment. 2) Responsiveness with indicators - (1) Responsive and friendly, (2) facilities physical, privacy and waiting times and (3) Competent and in accordance with Standard Operating Procedures. 3) Policy Implementation (PI) directly influenced health services with indicators - (1) Coverage of access, (2) Improvement of health (level and equity/level and equity) and (3) improvement of social financial risks as well as efficiency and equity) and 4 ) The indirect influence of Responsiveness (RPS) and the District Health System (DHS) through Policy Implementation (PI) on Health Services (HS) to improve optimal health status in TTU District, NTT Province

\section{Suggestion}

a) The results of this study can be used by the central government and District governments in analyzing the implementation of the District Health System Policy based on the determined indicators of success.

b) New Model- "Implementing the TTU District Health System Dominic BKG Policy" to improve health services and optimal community health status. This model can be used throughout Indonesia and the world with the same district characteristics.

c) For local government: Bapellitbang can identify indicators influence the implementation of the District Health System policy to improve health services through the use of a comprehensive, specific, and strategic Model of "Implementation of the Dominic BKG District Health System in TTU District" in the era of decentralization. Thus, public service interventions can be provided on target and in a directed and influenced setting for improving health services.

d) District / City Health Offices and Puskesmas and program managers can utilize this model for program improvement, compile strategic plans to improve health services in TTU District.

e) Educational institutions can strengthen efforts to develop health science and technology that are currently developing, for example through public policy advocacy and the implementation of DHS through district regulation to improve health services.

f) For public health, the new model can be included in the field of public administration in higher education and health colleges, health polytechnic in the subject of local content of the National Health System (SKN and District Health System (DHS)

g) For the community, this study is expected to actively participate in every government program in community empowerment that can improve the health status of the community for the influence of civil society health services.

h) The results of this study are expected to become a reference material in conducting further research and the making of PERDA DHS in other districts in East Nusa Tenggara

i) For researchers to conduct further research Evaluation of the District Health System policy in East Nusa Tenggara.

\section{Conflict of interest statement}

The authors declared that they have no competing interest.

\section{Statement of authorship}

The authors have a responsibility for the conception and design of the study. The authors have approved the final article.

\section{Acknowledgments}

The authors would like to thank the editor of IRJMIS for their valuable time, support, and advice in completing the present research.

Minggu, D., Benu, F. L., Gana, F., \& Kase, P. (2019). Development of district health system model policy implementation for improving health services. International Research Journal of Management, IT and Social Sciences, 6(5), 242-260. https://doi.org/10.21744/irjmis.v6n5.737 


\section{References}

Agarwal, R., Jain, P., Ghosh, M. S., \& Parihar, K. S. (2017). Importance of primary health care in the society. International Journal of Health Sciences, 1(1), 6-11. https://doi.org/10.21744/ijhs.v1i1.17

Aldim, -, Sholahuddin, A., \& Sadhana, K. (2018). Policy implementation of nazhir endowments. International Research Journal of Engineering, IT \& Scientific Research, 4(2), 63-72.

Archana, -, Datta, C., \& Tiwari, P. (2016). Impact of environmental degradation on human health. International Research Journal of Management, IT and Social Sciences, 3(1), 1-6.

Ayuningtyas, D. (2018). Kebijakan Kesehatan: Prinsip dan Praktik.

Browne, M. W., \& Cudeck, R. (1993). Alternative ways of assessing model fit. Sage focus editions, 154, 136-136.

Byrne, R. W., \& Russon, A. E. (1998). Learning by imitation: A hierarchical approach. Behavioral and brain sciences, 21(5), 667-684. https://doi.org/10.1017/S0140525X98001745

Dachi, R. A. (2017). Proses dan Analisis Kebijakan Kesehatan. Yogyakarta: Deepublish.

Edward, G. C. (Ed.). (1984). Public policy implementation. JAI Press.

Ghozali, I. (2017). Model Persamaan Struktural: Konsep dan Aplikasi dengan Program Amos 24 Edisi 7. Semarang: Universitas Diponegoro.

Grindle, M. S. (1980). Policy content and context in implementation. Politics and policy implementation in the Third World, 3-34.

Herabudin, H. (2019). Role of transportation department governance urban public transport in solok city. Jurnal Kelola: Jurnal Ilmu Sosial, 2(2), 11-20.

Kuntoro, H. (2009). Dasar Filosofis Metodologi Penelitian. Zifatama Publisher.

Ludji, I. D. R. (2014). Pengaruh Faktor Intra Personal "Social Ecological Model of Health Behaviour" Terhadap Penurunan Angka Kematian Ibu (AKI) di Kabupaten Kupang, NTT. Jurnal Info Kesehatan, 12(1), 649-660.

Mardika, I. N. (2017). Opposition of community citizenship against the policy of the village's leader. International Journal of Social Sciences and Humanities, 1(3), 74-87. https://doi.org/10.29332/ijssh.v1n3.57

Moore, J. H. (2003). The ubiquitous nature of epistasis in determining susceptibility to common human diseases. Human heredity, 56(1-3), 73-82. https://doi.org/10.1159/000073735

Nahak, S. (2017). Criminal law policy on land functions impacting climate change in Indonesian national law perspective. International Journal of Social Sciences and Humanities, 1(3), 28-39. https://doi.org/10.29332/ijssh.v1n3.50

Nahak, S. (2017). Penal mediation policy of land criminal offense resolution in the outer courts of Indonesia. International Research Journal of Engineering, IT \& Scientific Research, 3(2), 123-130.

Paramita, D. P., Adiatmika, I., Kuswardhani, T., \& Mustika, I. W. (2018). Physiological and psychosocial change and the need of health intervention model for elderly. International Journal of Health Sciences, 2(2), 61-67. https://doi.org/10.29332/ijhs.v2n2.160

Ratu Ludji, I. D. \& Bureni Y. (2015). Policy Brief Sistem Kesehatan Daerah (DHS) Kabupaten Timor Tengah Utara (TTU) Sebagai Pedoman Penyelenggaraan Pembangunan Kesehatan di Kabupaten TTU, Australia Indonesia Partnership for Health System Strengthening (AIPHSS), Australian Aid, Kemenkes RI, Kupang

Sugiyono, P. D. (2013). Metode Penelitian Manajemen. Bandung: Alfabeta, CV.

Van Meter, D. S., \& Van Horn, C. E. (1975). The policy implementation process: A conceptual framework. Administration \& Society, 6(4), 445-488. https://doi.org/10.1177\%2F009539977500600404

Wahab, S., \& Cooper, C. (2001). Tourism in the Age of Globalisation. Routledge.

Who, U. (2007). Iccidd. Assessment of iodine deficiency disorders and monitoring their elimination, 2.

Who, U. N. A. I. D. S., \& Unicef. (2009). Towards Universal Access: Scaling up priority HIV/AIDS interventions in the health sector.

World Health Organization. (2000). The world health report 2000: health systems: improving performance. World Health Organization. 